\title{
Morphological characterization of fruits, endocarp, seed and seedlings of cajá-manga (Spondias dulcis) ${ }^{1}$
}

\author{
Pedro Henrique Magalhães de Souza², Francielly Rodrigues Gomes ${ }^{2 *}$ (I) Givanildo Zildo da Silva², \\ Diego Ismael Rocha², Simério Carlos Silva Cruz², Danielle Fabíola Pereira da Silva²
}

$10.1590 / 0034-737 X 202168030010$

\begin{abstract}
The Cerrado biome has several species that can generate income, and the cajá-manga is one of these native species with great potential but with scarce information about its morphological characterization. Thus, this work aimed to characterize the fruit, endocarp, seeds, and seedlings of cajá-manga morphologically. The fruits were evaluated by the characteristics of the length, width, and diameter of the fruit, endocarp, and seeds, the number of loculi, and the weight of fruits and endocarp. The plantlets were evaluated for the number of seedlings per endocarp, number of leaflets, number of leaflets of the 3rd and 4th leaves, stem diameter, length of the shoot and root, root and shoot dry matter and data analyzed by descriptive analysis. The morphometric characteristics of the fruits, endocarp, and seeds were analyzed using the Scott-Knott test. The morphological characteristics of the fruits, the endocarps, the seeds, and the plantlets of cajá-manga varied within the mother plants. These results can be used as a basis for future selection of plants with desirable characteristics on breeding programs.
\end{abstract}

Keywords: fruit production; germination; genetic variability.

\section{INTRODUCTION}

Brazil has a diversity of plant species through its continental extension and geographical location and a great variation of climate and soil that make this territory suitable for the exploitation of natural resources with potential economic value (Silva et al., 2014).

The fruit species that occur in the different Brazilian biomes have the potential to be exploited sustainably and be inserted into the economic market through food production or as a source of raw material for pharmaceutical and cosmetic industries. However, further studies are needed, leading to the development of techniques that can allow commercial production and subsequent insertion of these species in the market (Damiani et al., 2011).

Among the species with economic potential in Brazil, there is the cajá-manga (Spondias dulcis), which can be also known as taperebá or cajarana, among other popular names. Exotic in Brazil, this species has its origin in the
Indo-Malaysia region of Tahiti, and it can be found in Asia, Australia, Central and South America, the Caribbean, and parts of Africa. In Brazil, this fruit tree is spread in almost the entire national territory, but it is predominant in the Midwest and Northeast regions (Santos et al., 2010; Silva et al., 2014).

The type of the fruits is ellipsoidal drupe and they are presented in the form of clusters, varying in quantity, with some protuberances and length of $6-9 \mathrm{~cm}$, besides thin and firm skin. The fruits are climacteric, they naturally fall from the tree when are fully developed and the epidermis turns into golden yellow color as they become ripe (Freitas \& Mattieto, 2013). The pulp is fleshy, fibrous, not too acid, and it has a strong smell; while the endocarp is large, white, and it has in its structure rigid and thick fibers that penetrate directly into the pulp (Silva et al., 2014). The seeds have physical and physiological dormancy, it being necessary to employ pre-germinative techniques to overcoming it (Souza et al., 2020).

Submitted on March $15^{\text {th }}, 2020$ and accepted on November $15^{\text {th }}, 2020$.

${ }^{1}$ This work is part of the master's degree dissertation of the first author and received financial support from CAPES and CNPq.

${ }^{2}$ Universidade Federal de Jataí, Jataí, Goiás, Brazil. pedrrromagalhaes@gmail.com; fram_rodgomes@hotmail.com; givanildozildo@gmail.com; diegoirocha@gmail.com; simerio@ufg.br; daniellefpsilva@ufg.br

*Corresponding author: fram_rodgomes@hotmail.com 
The phenotypic characterization of mother plants is important to select, identify, and indicate the best materials to cultivate perennial species (Farias Neto et al., 2004). The quality of these fruits is correlated with their morphology, making it necessary to carry out morphometric studies of the fruit, endocarp, and seeds. In certain circumstances, there is only the fruit, the seed, or the seedling for its recognition (Santos et al., 2010).

Morphological knowledge of fruits, seeds, and seedlings of cajá-manga are scarce, requiring studies to identify and optimize the domestication process. Therefore, the objective of this work was to characterize morphometrically the fruit, the endocarp, the seeds, and the seedlings of cajá-manga.

\section{MATERIAL AND METHODS}

The fruits of cajá-manga (Spondias dulcis) were harvested from six mother plants distanced $3.5 \mathrm{~km}$ from each other (Table 1), on natural vegetation that occurred on the municipality of Jataí - GO, whose annual average temperature is $23^{\circ} \mathrm{C}$ and the rainfall is $1700 \mathrm{~mm}$. Height measurements were made for each plant and the hypsometric height estimate was based on the method proposed by Batista (1998), ranging from 14.5 to $22.0 \mathrm{~m}$, and measurements of diameter at breast height (DBH) measured through the circumference at breast height $(\mathrm{CBH})$ at $1.30 \mathrm{~m}$, whose data were obtained using the formula $\mathrm{DBH}=\mathrm{CBH} / \pi$, standing between 60.2 and $73.0 \mathrm{~cm}$.

The harvest was performed manually with the aid of a hook and only fully ripe fruits with the peel completely yellow were harvested. Subsequently, the fruits were placed into plastic boxes $(55 \times 36 \times 31 \mathrm{~cm})$ and transported to the laboratory of the Federal University of Jataí.

For the morphometric analysis, 100 fruits per plant were used, in which the length, the width, the diameter, and the weight of fruits and endocarps were evaluated. The measurements were performed with the aid of a digital caliper with a precision of $0.01 \mathrm{~mm}$ and the weight was obtained in an analytical scale with a precision of $0.01 \mathrm{~g}$.

For the extraction of the endocarp, the fruits were cleaned by immersion and spray and sanitized in a solution of $2 \%$ sodium hypochlorite for 15 minutes. The fruits were subjected to extraction of the endocarp with the aid of a knife and running water, as recommended for the genus Spondias (Brasil, 2013).

To count the numbers of loculi per endocarp, the stones were sawn in half using a 12 " Fixed Saw Arch without damaging the seeds. After visual analysis of the diaspore, the average percentage of loculi and seeds per endocarp was calculated, which were extracted with the aid of tweezers. The seeds were evaluated for the length, the width, and the diameter with the aid of a digital caliper with a precision of $0.01 \mathrm{~mm}$.

The morphological analysis of seedlings was performed in a greenhouse and the plantlets were kept under controlled irrigation twice a day for ten minutes. One hundred seeds were sown in an expanded polystyrene tray $(35 \times 25 \times 5 \mathrm{~cm})$ over a uniform layer with $20 \mathrm{~cm}$ of moist sand and covered with a layer of $3 \mathrm{~cm}$. The emergence was evaluated every five days, considering the seeds that produced plantlets with normal characteristics. Sixty days after the emergence, the plantlets were analyzed for the number of seedlings, the number of seedlings per endocarp, the number of leaflets, the number of 3rd and 4th leaves leaflets, the shoot height, the stem diameter, the root length, the root and shoot dry matter.

For the morphological study of the seedlings, the descriptions were made with the aid of a binocular stereomicroscope and a digital camera. The structures of the seedlings were measured with a digital caliper and a ruler graduated in centimeters. The measurements of width, length and diameter were always performed in the median region of the seedling and at the root, $2 \mathrm{~mm}$ below the transition zone. The length measurements were particular for each structure: the first leaf and the central leaflet were measured from the base of the petiole to the apex; the first leaf and the central leaflet were measured from the base of the petiole to the apex of the cotyledon, the stem was measured from the collar to the insertion of the cotyledons; and the root was measured from the apex to the collar.

After the length evaluation, the seedlings were weighed on a precision scale. The weight of fresh matter (g/seedling) was obtained through the quotient between the sum of the weight of normal seedlings, divided by the

Table 1: Georeferencing of the mother plants and measurements of height $(\mathrm{H})$ and Diameter at Breast Height (DBH) of Spondias dulcis plants

\begin{tabular}{|c|c|c|c|}
\hline Mother Plant & Geographic coordinates & DBH (cm) & $\mathbf{H}(\mathbf{m})$ \\
\hline 1 & 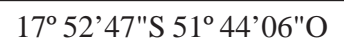 & 62.2 & 14.5 \\
\hline 2 & $17^{\circ} 54^{\prime} 55^{\prime \prime S} 51^{\circ} 44^{\prime} 05^{\prime \prime O}$ & 65.0 & 18.5 \\
\hline 3 & $17^{\circ} 53^{\prime} 51^{\prime \prime S} 51^{\circ} 43^{\prime} 24^{\prime \prime O}$ & 60.4 & 16.0 \\
\hline 4 & $17^{\circ} 51^{\prime} 39^{\prime \prime S ~} 51^{\circ} 43^{\prime} 45^{\prime \prime O}$ & 73.0 & 22.0 \\
\hline 5 & $17^{\circ} 53^{\prime} 06^{\prime \prime S ~} 51^{\circ} 43^{\prime} 32^{\prime \prime O}$ & 64.0 & 15.0 \\
\hline 6 & $17^{\circ} 53^{\prime} 57^{\prime \prime S} 51^{\circ} 44^{\prime} 05^{\prime \prime O}$ & 60.2 & 18.0 \\
\hline
\end{tabular}

Rev. Ceres, Viçosa, v. 68, n.3, p. 239-244, may/jun, 2021 
number of seedlings in the sample. To determine the weight of dry matter, the seedlings were taken in an oven with forced air circulation in paper bags at $65 \pm 2{ }^{\circ} \mathrm{C}$, for 72 hours and weighed on a precision scale $(0.001 \mathrm{~g})$.

The experiment was conducted in a completely randomized design. The obtained data were subjected to the test of normality and homogeneity, to the analysis of variance and tested by the $\mathrm{F}$ test. The averages were compared using the Scott-Knott test $(\mathrm{p}<0.01)$ in the software RBio (Bhering, 2017).

\section{RESULTS AND DISCUSSION}

The fruits of the cajá-manga type are drupe ovoid, with yellow gold color at physiological maturity, they have a smooth epidermis that varies from yellow to orange, the mesocarp is fleshy with yellow color, juicy pulp and bittersweet flavor (Figure 1 - A and B). These characteristics are consistent with the genus Spondias, in which the fruits are globose, oblong, ellipsoid and oblong-ovoid to obovoid as reported by Herrera et al. (2018) and Bohra \& Waman (2017).

When evaluating the fruit measurements, it is possible to observe that these characteristics varied among the plants. The mother plant 5 has fruits with greater length, width, diameter and weight, $76.59 \mathrm{~mm}, 56.98 \mathrm{~mm}, 54.91 \mathrm{~mm}$ and $145.18 \mathrm{~g}$, respectively; however, it did not differ in width and fresh weight of the fruits from the mother plant 4, which presented $54.29 \mathrm{~mm}$ and $131.82 \mathrm{~g}$, respectively (Table 2). The variability in the fruit size allows selecting mother plants with better quality to implant commercial orchards (Soares et al., 2006).

The length, diameter and weight values found in this study were similar to those evaluated by Chaves Neto \& Silva (2019), for S. dulcis fruits harvested in a mature stage in different microregions of Paraíba, who has moist and hot weather, with $65.64 ; 51.31 \mathrm{~mm}$ and $99.82 \mathrm{~g}$,
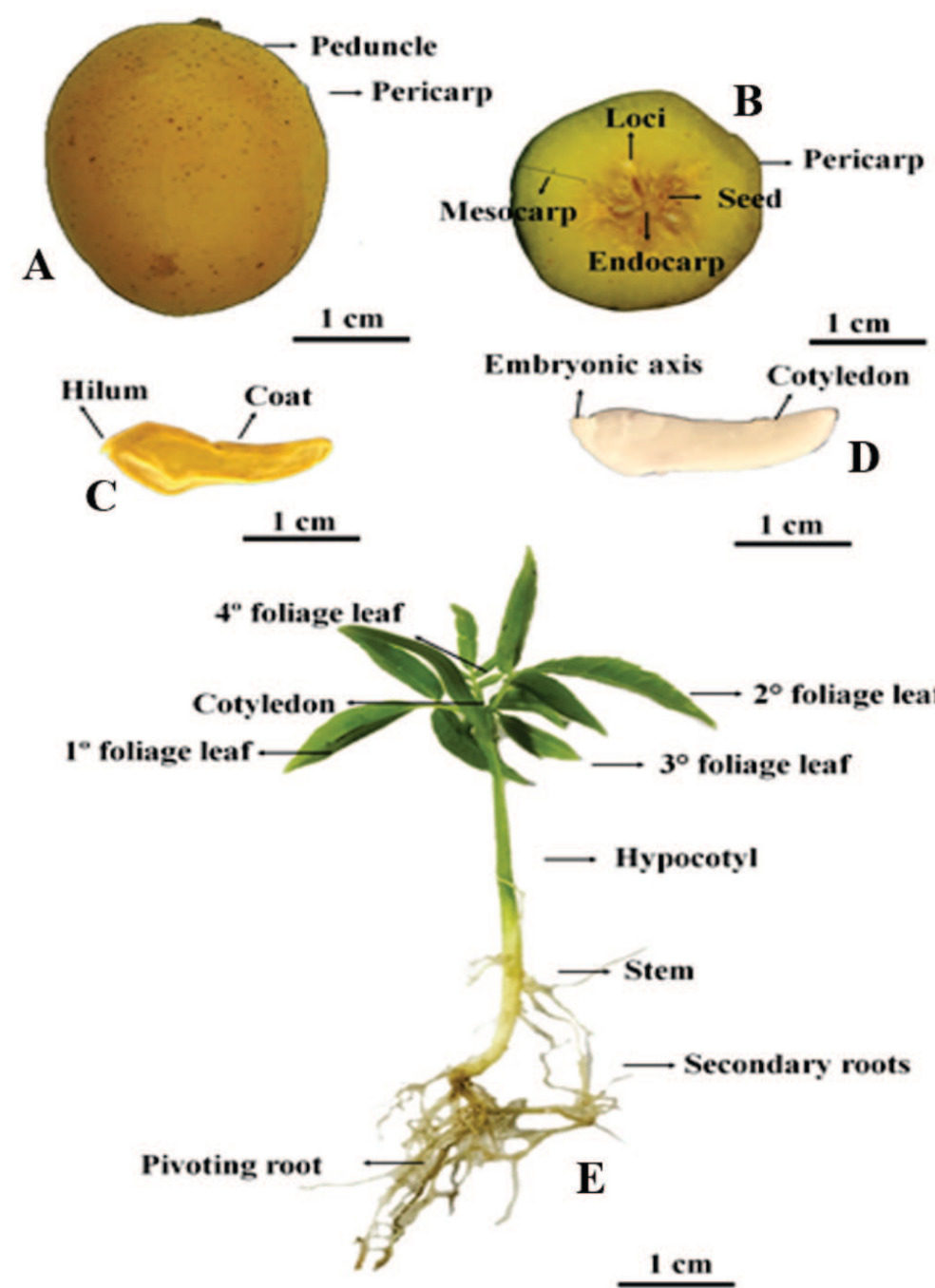

Figure 1: Morphological aspects of fruit, endocarp, seed, and seedlings of cajá-manga. (A) Front view of the fruit; (B) Cross-section of the fruit; (C) dorsal view of the outside of the seed; (D) Dorsal view of the seed embryo; (E) Seedling. 
respectively. These values are also similar to those measured by Bohra \& Waman (2017), in fruits harvested from S. dulcis in domestic orchards in India, with a tropical climate and high temperatures, whose values were $15.70,14.10 \mathrm{~mm}$ and $61.45 \mathrm{~g}$.

The fruits of Spondias dulcis are more elongated and wider, consequently, they are larger than other species of the genus Spondias. This fact is corroborated when compared to the fruits of umbu-cajazeira (Spondias sp.) from the semi-arid region of Bahia, which it had an average of 40.37, $32.34 \mathrm{~mm}$ and $16.27 \mathrm{~g}$ for length, diameter, and weight, respectively (Lima et al., 2015), Dutra et al. (2017), also found that umbuzeiro fruits ( $S$. tuberosa) from the semi-arid region had smaller width values than were evaluated in this work, $37.10 \mathrm{~mm}$. That difference in the size can be also due to the environment of the areas of collect since this species is well grown in regions with average temperatures close to $25^{\circ} \mathrm{C}$ and with high rainfall index (Hayati et al., 2019).

Larger fruits with greater length and width are important for commercialization and to be used by the industry for the production of products such as ice cream and popsicles (Lima et al., 2015; Nascimento et al., 2014). It should also be noted that the dimensions of fresh fruits are important characteristics for the processing industry and also for the acceptability of these fruits by the consumer market. The knowledge of these characteristics helps to identify and select genotypes with great potential (Lima et al., 2015).

The average weight values of the fruits are an important characteristic for the fresh fruit market since the fruits with the highest weights are also those of the largest sizes, which are the most attractive for consumers. Bosco et al. (2000) classified fruits for the genus Spondias as large (fresh weight $>15 \mathrm{~g}$ ), medium (between 12 and $15 \mathrm{~g}$ ), and small (weight $<12 \mathrm{~g}$ ). Based on this classification, all mother plants produced large fruits. However, the average fresh weight of fruits is a flexible characteristic that can vary from species to species within the genus and when they reach their full physiological development, as reported by Gondim et al. (2013) on their work with umbu-cajazeira (Spondias sp.).

The endocarp, popularly known as "stone", is of the nuculanium type, is characterized by being large, creamwhite, subero-lignified with rigid fibers wrapped around the seeds. These characteristics were reported by Quadros et al. (2015) in the characterization of five mother plants of Spondias mombin, located in the physical base of Embrapa Amazônia Oriental. Herrera et al. (2018) reported in their review of the morphology and anatomy of Anarcadiaceae fruits, that the surface of the endocarp has long, longitudinal and thick fibers forming bristles that penetrate the parenchyma, in which a peripheral fibrous network can be formed around.
All structures up to the seed are characterized by making it difficult to germinate, constituting a physical barrier that prevents oxygen and water from entering the embryo. The lower weight of the endocarps correlates with a greater amount of weight of the fruits, an important factor for the food industry (Cavalcante et al., 2009; Carvalho \& Nakagawa, 2012; Quadros et al., 2015).

The size of the endocarps varied between the plants, in which those from the mother plant 4 showed higher values for length, width, diameter, and fresh weight, 29.76 $\mathrm{mm}, 28.53 \mathrm{~mm}, 28.34 \mathrm{~mm}$ and $18.52 \mathrm{~g}$, respectively; however, it did not differ from the fresh weight of those from mother plant 5, in which $17.24 \mathrm{~g}$ were found (Table 2).

The measurements of the length, the diameter and the fresh weight of the endocarps were higher when compared to other species from the same genus, as for $S$. mombin evaluated by Marques et al. (2018), which it was $30.38 \mathrm{~mm}$, $18.11 \mathrm{~mm}$ and $4.98 \mathrm{~g}$, respectively, and for fruits of $S$. tuberosa evaluated by Dutra et al. (2017), with $24.45 \mathrm{~mm}$, $11.91 \mathrm{~mm}$ and $2.54 \mathrm{~g}$, respectively. The size of the fruit and endocarp can be an important characteristic to differentiate the $S$. dulcis from other species of the genus Spondias, since their size is greater than the others of the genus.

Regarding the pulp weight, the mother plant 5 had an average of $127.94 \mathrm{~g}$, however, it did not differ from the mother plant 4, which has an average of $113.30 \mathrm{~g}$ (Table 2). According to Costa et al. (2015), different values for some characteristics, such as pulp weight, can be influenced by the soil, environmental conditions, age of the plants and also by the genetic difference, and this characteristic is important to select plants with fruits with better quality. Damiani et al. (2011), evaluating $S$. dulcis pulps reported a pulp yield of $61.02 \%$, which consisted of $87.4 \mathrm{~g}$ of pulp. Lima et al. (2015), and Marques et al. (2018), evauating Spondias sp. and S. mombin fruits founded pulp weight of $16.27 \mathrm{~g}$ and $7.80 \mathrm{~g}$, respectively, which are lower than those found in this study for the weight of $S$. dulcis pulp. It indicates that was high variability within the genus and the specie, and through this variation is possible to select plants that produce fruits with high industry yield.

For the number of loculi, it was verified that the mother plant 5 presented endocarps with a larger number of loculi, with 4.9; however, there was no difference from the mother plant 4, in which an average of 4.4 loculi was found (Table 2).

This characteristic can vary from species within the same genus and can help to characterize different species from the genus Spondias (Souza et al., 2000), as it was possible to the species $S$. mombin, in which were founded fruits with 4.92 and 5.14 loculi by Quadros et al. (2015), 4.9 to 4.4 by Marques et al. (2018), and 3.0 to 4.0 loculi by Souza et al. (2000). Brito Neto et al. (2009), founded fruits of $S$. tuberosa with 1.0 loculi per endocarp. The loculi number is related to the number of seeds per endocarp and 
can help to select fruits that produce more seeds and use it on the propagation of the species.

The seeds are claviform, elongated, with the integument differentiated into two membranaceous structures, testa (cream color) and tegmen. The embryo is axial, similar to the seed, and with a light cream color, the cotyledons are flat and fleshy (Figure 1-C and D).

In the morphological analysis, it was verified $24 \%$ of germination and an average of 1.42 seedlings per endocarp. Each seedling had an average of 6 leaves, the number of leaflets on the 3rd and 4th leaves was 3.58 and 3.42. It was observed that the leaves are alternated, lanceolate, and have 3 to 5 leaflets per leaf at 60 days after sowing. The first pair of foliage leaves are composed, trifoliate, opposite, and straight. The leaflets are sessile, green, with both smooth faces, with the main vein; lance-shaped, acute apex, and serrated margins. The second pair of foliage leaf develops alternately, is composed, unpaired, with five leaflets, similar to the first pair. Cotyledons are opposite, linear, green, and sessile (Figure 1 - E).

The shoot height, stem diameter, and root length presented average values of $37.49,2.57$, and $10.32 \mathrm{~mm}$, respectively. The dry weight of root and shoot was 0.26 and $0.20 \mathrm{~g} / \mathrm{seedling}^{-1}$, respectively. The morphological study of seedlings is a determining factor for the knowledge of the vegetative cycle of the species. Observing the development of seedling helps to differentiate the taxonomic characteristics of the species that are similar to each other and in studies of seed technology, such as tests to evaluate germination and vigor (Silva et al., 2008).

The emergence of cajá-manga is of the epigeous phanerocotyledonal type. The endocarp can have more than one seed, the protrusion of the primary root is surrounded by the fibers of the endocarp, and more than one root can emerge in the truncated or flattened part of the endocarp (Azevedo et al., 2004). Initially, the root is cylindrical, glabrous, and hyaline; at this stage, the protrusion of the hypocotyl was observed in a curved form at the same end where the protrusion of the root occurs. In the evaluation of the seedlings, it was possible to identify the emergence of more than one normal seedling per endocarp. However, only one seedling had a vigorous root, larger size, and presence of secondary roots, a fact also reported by Mitchell \& Daly (2015) for this same species.

The biometrical characterization of fruits is an important tool to determine the genetic variability between subjects from the same species and support breeding programs (Lourenço et al., 2013). Thus, the results obtained on this work will contribute significantly to the spread of scientific knowledge regarding this species and to the formation of orchards that will produce fruits with high quality.

Table 2: Fruit length (FL), fruit width (FW), fruit diameter (FD), fresh fruit weight (FFW), endocarp length (EL), endocarp width (EW), endocarp diameter (ED), fresh endocarp weight (FEW), weight of the pulp (WP) and number of loculi (NL) of one hundred cajá-manga fruits obtained from six mother plants

\begin{tabular}{|c|c|c|c|c|c|}
\hline Mother plant & FL $(\mathbf{m m})$ & FW (mm) & FD $(\mathbf{m m})$ & FFW $(\mathbf{g})$ & $\mathbf{E L}$ \\
\hline 1 & $71.22 \mathrm{~b}$ & $50.38 \mathrm{~b}$ & $47.83 \mathrm{c}$ & $89.77 \mathrm{~b}$ & $26.05 \mathrm{c}$ \\
\hline 2 & $59.30 \mathrm{~d}$ & $41.47 \mathrm{c}$ & $40.26 \mathrm{~d}$ & $70.79 \mathrm{c}$ & $23.98 \mathrm{~d}$ \\
\hline 3 & $64.91 \mathrm{c}$ & $50.75 \mathrm{~b}$ & $47.53 \mathrm{c}$ & $110.33 \mathrm{~b}$ & $27.17 \mathrm{~b}$ \\
\hline 4 & $72.74 \mathrm{~b}$ & $54.29 \mathrm{a}$ & $51.60 \mathrm{~b}$ & $131.82 \mathrm{a}$ & $29.76 \mathrm{a}$ \\
\hline 5 & $76.59 \mathrm{a}$ & $56.98 \mathrm{a}$ & $54.91 \mathrm{a}$ & $145.18 \mathrm{a}$ & $25.85 \mathrm{c}$ \\
\hline 6 & $70.07 \mathrm{~b}$ & $49.85 \mathrm{~b}$ & $48.89 \mathrm{c}$ & $101.85 \mathrm{~b}$ & $28.07 \mathrm{~b}$ \\
\hline Overall & 69.14 & 50.62 & 48.50 & 108.29 & 26.81 \\
\hline $\mathrm{CV}(\%)$ & 6.27 & 6.84 & 4.22 & 18.57 & 4.42 \\
\hline Standard deviation & 7.00 & 5.86 & 4.91 & 31.60 & 2.15 \\
\hline Mother plant & $\mathbf{E W}(\mathbf{m m})$ & ED $(\mathbf{m m})$ & FEW (g) & WP $(g)$ & NL \\
\hline 1 & $23.12 \mathrm{c}$ & $22.80 \mathrm{c}$ & $11.30 \mathrm{c}$ & $78.47 \mathrm{~b}$ & $3.8 \mathrm{~b}$ \\
\hline 2 & $22.06 \mathrm{~d}$ & $21.91 \mathrm{c}$ & $9.89 \mathrm{c}$ & $60.89 c$ & $3.3 \mathrm{c}$ \\
\hline 3 & $25.27 \mathrm{~b}$ & $25.51 \mathrm{~b}$ & $13.50 \mathrm{~b}$ & $96.83 \mathrm{~b}$ & $3.8 \mathrm{~b}$ \\
\hline 4 & $28.53 \mathrm{a}$ & $28.34 \mathrm{a}$ & $18.52 \mathrm{a}$ & $113.30 \mathrm{a}$ & $4.4 \mathrm{a}$ \\
\hline 5 & $23.63 \mathrm{c}$ & $24.75 \mathrm{~b}$ & $17.24 \mathrm{a}$ & $127.94 \mathrm{a}$ & $4.9 \mathrm{a}$ \\
\hline 6 & $24.59 \mathrm{~b}$ & $25.28 \mathrm{~b}$ & $13.89 \mathrm{~b}$ & $87.95 \mathrm{~b}$ & $3.1 \mathrm{c}$ \\
\hline Overall & 24.53 & 24.77 & 14.06 & 94.23 & 3.88 \\
\hline$\overline{\mathrm{CV}(\%)}$ & 4.85 & 4.74 & 17.53 & 21.76 & 22.20 \\
\hline Standard deviation & 2.36 & 2.36 & 3.86 & 29.62 & 0.99 \\
\hline
\end{tabular}

Averages followed by the same letter in the column are not different by the Scott-Knott test $(\mathrm{P}<0.01)$. 


\section{CONCLUSIONS}

The morphological description of the fruits, the endocarps, the seeds, and the plantlets of cajá-manga indicates that the characteristics vary between the plants.

The results of morphological characterization will be used as a basis for future selection of plants with desirable characteristics on breeding programs and could contribute to species conservation.

\section{ACKNOWLEDGEMENTS, FINANCIAL SUPPORT AND FULL DISCLOSURE}

The authors thank the Coordenação de Aperfeiçoamento de Pessoal de Nível Superior (CAPES) and the Conselho Nacional de Desenvolvimento Científico e Tecnológico (CNPq) for financial support. The authors declare that have no conflict of interest.

\section{REFERENCES}

Azevedo DM, Mendes AM \& Figueiredo AF (2004) Característica da germinação e morfologia do endocarpo e plântula de taperebá (Spondias mombim L.) - Anarcadiaceae. Revista Brasileira de Fruticultura, 26:534-537.

Batista JLF (1998) Mensuração de árvores: uma introdução à dendrometria. Master Dissertation. Escola Superior de Agricultura "Luiz de Queiroz", Universidade de São Paulo, Piracicaba. $73 \mathrm{p}$.

Bhering LL (2017) RBio: A tool for biometric and statistical analysis using the $\mathrm{r}$ platform. Crop Breeding and Applied Biotechnology, 17:187-190.

Bohra P \& Waman AA (2017) Spondias dulcis L.: An important acidulant species in bay islands. International Journal of Forest Usufructs Management, 18:25-29.

Bosco J, Soares KT, Aguiar Filho SD \& Barros RV (2000) A cultura da cajazeira. João Pessoa, EMEPA. 29p.

Brasil, Ministério da Agricultura, Pecuária e Abastecimento (2013) Instruções para análise de sementes de espécies florestais. Brasília, MAPA. 98p.

Brito Neto JF, Lacerda JS, Pereira WE, Albuquerque R, Costa APM \& Santos P (2009) Emergência de plântulas e características morfológicas de sementes e plantas de umbuzeiro. Engenharia Ambiental, 6:224-230.

Carvalho NM \& Nakagawa J (2012) Sementes: ciência, tecnologia e produção. $5^{\text {th }}$ ed. Jaboticabal, FUNEP. 590p.

Cavalcante LF, Lima EMD, Freire JLDO, Pereira WE, Costa ADPMD \& Cavalcante IHL (2009) Componentes qualitativos do cajá em sete municípios do brejo paraibano. Acta Scientiarum. Agronomy, 31:627-632.

Chaves Neto JRC \& Silva SM (2019) Caracterização física e físico-química de frutos de Spondias dulcis Parkinson de diferentes microrregiões do Estado da Paraíba. Colloquium Agrariae, $15: 18-28$.

Costa FR, Rêgo ER, Rêgo MM, Neder DG, Melo Silva S \& Schunemann APP (2015) Análise biométrica de frutos de umbuzeiro do semiárido brasileiro. Bioscience Journal, $31: 682-690$

Damiani C, Silva FAD, Amorim CCDM, Silva STP, Bastos IM, Asquieri ER \& Vera R (2011) Néctar misto de cajá-manga com hortelã: caracterização química, microbiológica e sensorial. Revista Brasileira de Produtos Agroindustriais, 13:301-309.
Dutra FV, Cardoso AD, Morais OM, Viana AES, Melo TL \& Júnior NDSC (2017) Características físicas e químicas de acessos de umbuzeiros (Spondias tuberosa Arr. Cam). Revista de Ciências Agrárias, 40:140-149.

Farias Neto JTD, Carvalho JUD \& Muller CH (2004) Estimativas de correlação e repetibilidade para caracteres do fruto de bacurizeiro. Ciência e Agrotecnologia, 300-305.

Freitas DDGC \& Mattietto RDA (2013) Ideal sweetness of mixed juices from Amazon fruits. Food Science and Technology, 33:148-154

Gondim PJ, Silva SDM, Pereira WE, Dantas AL, Chaves Neto JR \& Santos LFD (2013) Qualidade de frutos de acessos de umbucajazeira (Spondias sp.). Revista Brasileira de Engenharia Agrícola e Ambiental, 17:1217-1221.

Hayati I, Hartana A \& Djuita NR (2019) Modeling climatic suitable areas for kedondong (Spondias dulcis) cultivation in central part of Sumatra, Indonesia. Biodiversitas Journal of Biological Diversity, 20:3608-3618.

Herrera F, Mitchell JD, Pell SK, Collinson ME, Daly DC \& Manchester SR (2018) Fruit morphology and anatomy of the Spondioid Anacardiaceae. The Botanical Review, 84:315-393.

Lima MSS, Dantas ACVL, Fonseca AAO \& Barroso JP (2015) Caracterização de frutos de genótipos selecionados de umbucajazeira (Spondias sp.). Interciência, 40:311-316.

Lourenço IP, Figueiredo RW, Alves RE, Aragão FAS, Moura CFH (2013) Caracterização de frutos de genótipos de muricizeiros cultivados no litoral cearense. Revista Ciência Agronômica, 44:499-504.

Marques CS, Guimarães PVP, Smiderle OJ \& Durigan MFB (2018) Qualidade agroindustrial de frutos de taperebazeiros (Spondias mombin L.) cultivados em áreas urbanas de Boa vista, Roraima. Revista Ambiente: Gestão e Desenvolvimento, 11:296-307.

Mitchell JD \& Daly DC (2015) A revision of Spondias L.(Anacardiaceae) in the Neotropics. PhytoKeys, 55:1-92.

Nascimento RS, Cardoso JÁ \& Cocozza FD (2014) Caracterização física e físico-química de frutos de mangabeira (Hancornia speciosa Gomes) no oeste da Bahia. Revista Brasileira de Engenharia Agrícola e Ambiental, 18:856-860.

Quadros BR, Ribeiro OD, Rodrigues Junior OM, Nascimento WMO, Cavariani C \& Nascimento E (2015) Biometria do endocarpo de taperebá (Spondias mombin L.-Anacardiaceae). Revista Cultivando o Saber, 8:250-256

Santos MBD, Cardoso RL, Fonseca AADO \& Conceição MDN (2010) Caracterização e qualidade de frutos de umbu-cajá (Spondias tuberosa x S. mombin) provenientes do recôncavo sul da Bahia. Revista Brasileira de Fruticultura, 32:1089-1097.

Silva GA, Brito NJN, Santos ECG, López JA \& Almeida MG (2014) Gênero Spondias: aspectos botânicos, composição química e potencial farmacológico. Biofar, 10:27-41.

Silva KB, Alves EU, Bruno RDLA, Matos VP \& Gonçalves EP (2008) Morfologia de frutos, sementes, plântulas e plantas de Erythrina velutina willd., leguminoseae - Papilionideae. Revista Brasileira de Sementes, 30:104-114.

Soares EB, Gomes RLF, Carneiro JGDM, Nascimento FND, Silva ICV \& Costa JCLD (2006) Caracterização física e química de frutos de cajazeira. Revista Brasileira de Fruticultura, 28:518519.

Souza PHM, Ragagnin ALSL, Ribeiro RC, Silva GZ, Rocha DI \& Silva DFP (2020) Dormancy overcoming in seeds of cajá-manga (Spondias dulcis). Comunicata Scientiae, 11:01-06

Souza FX, Sousa FHL, Freitas JBS \& Rossetti AG (2000) Aspectos morfológicos da unidade de dispersão de cajazeira. Pesquisa Agropecuária Brasileira, 35:215-220. 